\title{
Conservation of threatened relict trees through living ex situ collections: lessons from the global survey of the genus Zelkova (Ulmaceae)
}

\author{
Gregor Kozlowski • Douglas Gibbs • Fan Huan • David Frey • \\ Joachim Gratzfeld
}

Received: 5 July 2011/Accepted: 2 December 2011/Published online: 21 December 2011

(C) Springer Science+Business Media B.V. 2011

\begin{abstract}
Maintaining living ex situ collections is one of the key conservation methods in botanic gardens worldwide. Despite of the existence of many other conservation approaches used nowadays, it offers for many endangered plants an important insurance policy for the future, especially for rare and threatened relict trees. The aim of this research was to investigate the global extent of living ex situ collections, to assess and discuss their viability and inform the development of conservation approaches that respond to latest global conservation challenges. We used as a model taxon the tree genus Zelkova (Ulmaceae). The genus includes six prominent Tertiary relict trees which survived the last glaciation in disjunct and isolated refugial regions. Our comprehensive worldwide survey shows that the majority of botanic institutions with Zelkova collections are in countries with a strong horticultural tradition and not in locations of their origin. More importantly, the acutely threatened Zelkova species are not the most represented in collections, and thus safeguarded through ex situ conservation. Less than $20 \%$ of the ex situ collections surveyed
\end{abstract}

Electronic supplementary material The online version of this article (doi:10.1007/s10531-011-0207-9) contains supplementary material, which is available to authorized users.

G. Kozlowski $(\square) \cdot$ D. Frey

Department of Biology and Botanic Garden, University of Fribourg,

Chemin du Musée 10, 1700 Fribourg, Switzerland

e-mail: gregor.kozlowski@unifr.ch

G. Kozlowski

Natural History Museum, Chemin du Musée 6, 1700 Fribourg, Switzerland

D. Gibbs · J. Gratzfeld

Botanic Gardens Conservation International (BGCI), 199 Kew Road, Richmond,

Surrey TW9 3BW, United Kingdom

F. Huan

Xishuangbanna Tropical Botanical Garden, Chinese Academy of Sciences,

Menglun Township, Mengla County, Yunnan 666303, China

D. Frey

Department of Geosciences, Conservation Biogeography, University of Fribourg,

Chemin du Musée 4, 1700 Fribourg, Switzerland 
contain plant material of known wild provenance while the majority $(90 \%)$ of collections are generally very small (1-10 trees). Botanic gardens and arboreta particularly in regions where iconic relict trees naturally occur should play a vital role in the conservation of these species. The coordination of conservation efforts between gardens has to be enhanced to prioritise action for the most threatened relict trees. Large scale genetic studies should be undertaken, ideally at genus level, in order to verify or clarify the provenance of ex situ collections of relict trees in cultivation. For the most threatened relict tree genera, wellcoordinated specialist groups should be created.

Keywords Botanic gardens - Collection strategy - Ex situ conservation - Global strategy for plant conservation - Tertiary relict trees $\cdot$ Threatened plant species

\section{Introduction}

Trees, and especially relict trees, represent an evolutionary heritage of disproportionate significance for conservation of plant diversity (Petit et al. 2005). They have attracted the attention of naturalists and scientists for many centuries and their cultivation in botanic gardens and arboreta has a long tradition (Maunder et al. 2004). In the past, however, the main interest was geared towards exploitation of species with economic and ornamental potential (Donaldson 2009). Only in the last half century botanic gardens have devoted more attention and resources into conservation issues. Rapid global change will confront the conservation of rare and threatened organisms, and especially relict trees, with new challenges (Guerrant et al. 2004; Oldfield 2009). In consequence, practically all botanic gardens and arboreta consider today the conservation of threatened species as one of their most important missions (Powledge 2011).

One of the most topical questions, however, is how modern botanic gardens should maintain their collections and which methods are the most appropriate to struggle efficiently against extinctions (Powledge 2011). Today, the spectrum of well established and newly developed ex situ conservation methods and approaches is very large, e.g., (1) maintaining living ex situ collections (open-air cultivation of plants in display or reference collections); (2) cultivation in controlled environment (e.g. in heated greenhouses); (3) cryopreservation of seeds, spores, pollen, propagules, etc. frozen in liquid nitrogen; (4) seed banking with seeds stored under low moisture and temperature; and (5) in vitro tissue culture and propagation (Maunder et al. 2004). Besides of their ex situ activities, botanic gardens and arboreta are today very important initiators and/or partners of innumerable in situ conservation projects. Their skills and know-how are particularly important in several conservation approaches proposed and developed recently, e.g., in inter situ conservation (Burney and Burney 2007, Cochrane et al. 2010), quasi in situ conservation (Volis and Blecher 2010) or in situ forest genebanks (Ledig 1988, Uma Shaanker et al. 2002).

Despite of this arsenal of approaches used nowadays, maintaining living ex situ collections offers for many endangered trees an important insurance policy for the future (Oldfield 2009). An illustrative example of a tree species saved from extinction through ex situ conservation is the one of Franklinia alatamaha (Theaceae). This small tree was discovered in 1765 in Georgia (USA), disappeared completely from the wild around 1800, and survived only due to precocious propagation in a garden collection (Owens and Rix 2007). Not only the degree of rarity, however, should be taken into consideration when prioritizing ex situ conservation of trees. Special attention should be given to relict trees. 
Taxonomically often isolated, they provide a unique opportunity to understand past and recent biogeographical and evolutionary processes. Their scientific value, therefore, is inestimable. A well-known example is Ginkgo biloba, a "living fossil" and the only representative of the isolated gymnosperm group (Chaw et al. 2000). Although several relict natural populations of G. biloba have been found in China (Del Tredici et al. 1992) the survival of this taxon was secured during the last two millennia due to ex situ cultivation and propagation (Zhao et al. 2010).

In Europe and Western Asia prominent Tertiary relict trees belonging to genera such as Albizia, Gleditsia, Juglans, Liquidambar, Parrotia, Pterocarya and Zelkova, survived the last glaciation only in isolated refugial regions and/or on Mediterranean islands (Quézel and Médail 2003; Garfî et al. 2011). In addition to their scientific value, the majority of these relict trees contribute to human welfare and represent a non-negligible part of the total economic value of biodiversity, at least locally. In many regions relict trees play to this day an important role in timber industry and/or handicraft enterprise of local populations (e.g. Parrotia and Zelkova; Rackham and Moody 1996; Kvavadze and Connor 2005; Sefidi et al. 2011) or are used as important agents for slope stabilization against erosion and landslides (e.g. Gleditsia and Parrotia; Bibalani et al. 2006). Relict trees also have an important ethnobotanical and/or medicinal utilization (e.g. Fernandez et al. 2005; Zheng et al. 2006; Ahanjan et al. 2007; Sadighara et al. 2009) or can be used in detoxification of soil and water (Mahvi et al. 2007). Many relict trees might be, additionally, important resources of genes for resistance to plant pathogens. Zelkova abelicea, for example, proved to be resistant to the Dutch Elm Disease and could become, therefore, an important taxon in breeding programmes to enhance resistance to pests in the Ulmaceae family (Sondergaard and Egli 2006).

Relict trees are ancient organisms which were able to cope with changing environmental conditions for million of years. Many of these taxa have a very restricted distribution today with often only few natural populations. Prominent examples are Metasequoia glyptostroboides (Tang et al. 2011) and Glyptostrobus pensilis (Li and Xi 2005). Although at present functionally marginal for the maintenance of ecosystem processes in extant plant communities, they could be much more important in the future (Loreau et al. 2001). It has been estimated that the composition of one-third of the planet's forests could be altered markedly as a result of climate change (Melillo 1999; Iverson and Prasad 2001). Relict trees could prove vital in the future establishment and management of novel ecosystems with new species combinations. Thus, relict trees not only deliver ecosystem goods and services today (Costanza et al. 1997) but they might play an important role in maintaining ecosystem functions in times of rapid global change in the near future.

The relict genus Zelkova of the elm family (Ulmaceae), used as a model taxon in the present study, comprises six monoecious tree species (Wiegrefe et al. 1998; Denk and Grimm 2005) (Table 1). Once, many million years ago, widely distributed in the Northern Hemisphere, and also reported from North America in the Early Cainozoic (Burnham, 1986) today this genus shows a disjunct distribution (Appendix S1 in Supplementary Material). Three Zelkova species occur in eastern Asia (Z. serrata, Z. schneideriana and Z. sinica; Zheng-yi and Raven 2003), one in western Asia (Z. carpinifolia) and two in the Mediterranean region, Z. sicula from Sicily and Z. abelicea from Crete (Denk and Grimm 2005). This makes the genus Zelkova an important and emblematic object for multidisciplinary research and conservation planning.

In this study we are focusing on living ex situ collections, the most traditional and popular ex situ conservation method, in order to address the viability of this approach for 
Table 1 Extant species of Zelkova (accepted names with the most commonly used synonyms in brackets), their natural distribution by countries and IUCN Red List categories

\begin{tabular}{lll}
\hline Species & Distribution & $\begin{array}{l}\text { RL } \\
\text { category }\end{array}$ \\
\hline Z. sicula & Sicily (Italy) & CR \\
Z. abelicea (Z. cretica) & Crete (Greece) & EN \\
Z. carpinifolia (Z. ulmoides, Z. crenata, Z. hyrcana) & Turkey, Georgia, Armenia, & NT \\
$\begin{array}{ll}\text { Z. serrata (Z. formosana, Z. keaki, Z. acuminata, Z. hirta, , Japan, Korea, Kuril Islands } \\
\text { Z. tarokoensis, Z. japonica) }\end{array}$ & NE \\
$\begin{array}{l}\text { Z. schneideriana } \\
\text { Z. sinica }\end{array}$ & China & NE \\
\hline
\end{tabular}

$C R$ critically endangered, $E N$ endangered, $N T$ near threatened, $N E$ not evaluated

conservation, identify gaps and recommend improvements for future management options. Drawing on the preliminary results of the Global Survey of ex situ Zelkova Collections (BGCI 2010) the aim of this study was to investigate the global extent of living ex situ collections of a relict tree genus. The following questions were addressed: (1) Are all Zelkova species represented in ex situ collections? (2) What is the global distribution and diversity of Zelkova ex situ collections? (3) To which extent are Zelkova ex situ collections held in countries and regions of their origin? (4) Are the most threatened Zelkova species particularly represented, and thus safeguarded through ex situ conservation? (5) What information do we have regarding the provenance of the cultivated material? (6) What is the average size of Zelkova ex situ collections kept worldwide in botanic gardens and arboreta? The results of this study, allow us to offer concrete recommendations for the conservation of the most threatened Zelkova species, and to develop a coordinated strategy for the long term conservation of the genus.

\section{Materials and methods}

We carried out a survey of ex situ collections of all six species of the genus Zelkova through a range of methods, including an analysis of data and information obtained through: (1) PlantSearch database of Botanic Gardens Conservation International (www. bgci.org/plant_search.php); (2) Direct liaison with botanic gardens, arboreta and networks holding Zelkova collections; (3) Online databases of living collections: specifically the multisite BG-BASE search facility maintained by Royal Botanic Garden Edinburgh (rbgweb2.rbge.org.uk/multisite/multisite3.php) and the Database of Asian Plants in Cultivation of Quarryhill Botanical Garden and California Academy of Sciences (research.calacademy.org/research/botany/quarryhill/index.asp). For the purpose of this survey, a record/ collection is the presence of a single living Zelkova taxon within an institution and may include multiple accessions and/or individuals.

All of BGCI's institutional members were invited to contribute to the survey. However, participation in the survey was not limited to BGCI members and was sought and promoted 
through BGCI's website (www.bgci.org) as well as through a number of mailing lists, networks and organizations including: American Public Gardens Association (APGA), Botanic Gardens Committee of the Chinese Academy of Sciences (CAS), and European Botanic Gardens Consortium.

In addition to the presence or absence of a Zelkova species from a collection, two further issues were raised in the survey: (1) Is(are) the Zelkova collection(s) from a known wild source or from horticultural/unknown origin? and (2) What is the approximate size of the collection? Five categories of the collection size were defined: 1 individual, 2-10 individuals, 11-30 individuals, 31-50 individuals, and more than 50 individuals.

The taxonomic division of the genus follows Denk and Grimm (2005), with all survey submissions relating to accepted names and most common synonyms of Zelkova (Table 1) included in the analysis.

\section{Results}

Our survey shows that all Zelkova taxa are currently held in living collections by botanic gardens and arboreta. In total, 275 Zelkova records, from 146 institutions in 27 countries were identified (Appendix S2). Figure 1 reveals that the United States, United Kingdom and Germany are the most common countries for ex situ conservation of the genus Zelkova. These three nations contain more than $40 \%$ of all botanic gardens and arboreta with Zelkova in cultivation (Fig. 1a), and nearly $50 \%$ of all Zelkova ex situ collections worldwide (Fig. 1b). Other important countries with numerous ex situ collections are China, France, Australia, Belgium, Denmark and Italy.

All Zelkova species are found only to a limited degree in the countries of their origin (Fig. 2 and Appendix S2). According to our survey, this applies first and foremost to China, where 25 ex situ collections of $Z$. serrata, Z. schneideriana and Z. sinica could be identified. Only 2-3 ex situ collections are held in the countries of origin for Z. sicula, Z. abelicea and Z. carpinifolia. The same trend can be observed for the rarest Zelkova species with the smallest natural distribution in Fig. 3: of the 275 collections included in our analysis, just 25 records of the most threatened Zelkova taxa (Z. sicula and Z. abelicea) were noted. The highest number of ex situ collections was found for the most widely distributed taxon Z. serrata with 110 records worldwide (Fig. 3), followed by Z. carpinifolia, Z. schneideriana and Z. sinica, with 60, 47 and 33 ex situ collections respectively.

The proportion of well-documented ex situ collections is very low. Generally, only $20 \%$ of ex situ collections are of known wild provenance (Fig. 3). For Z. carpinifolia only 2 records (3\%) with known wild origin were found. Unique is the situation of Z. sicula. The species is so rare in the wild and in horticulture that the collections identified in this survey are certainly based on wild collected material since there was only one population known until 2009.

Our survey resulted in 132 records with known number of trees in the given ex situ collection (Fig. 4 and Appendix S2). The overwhelming majority (90\%) of collections are very small, with either only one tree (52 ex situ collections surveyed) or between 2 and 10 individuals (67 collections). Data were obtained from only three collections holding more than 30 trees of one species: (1) The Gannan Arboretum of Jiangxi, China; (2) The Dawes Arboretum, USA (both Z. serrata); and (3) Tbilisi Botanic Garden and Institute of Botany, Georgia (Z. carpinifolia). 

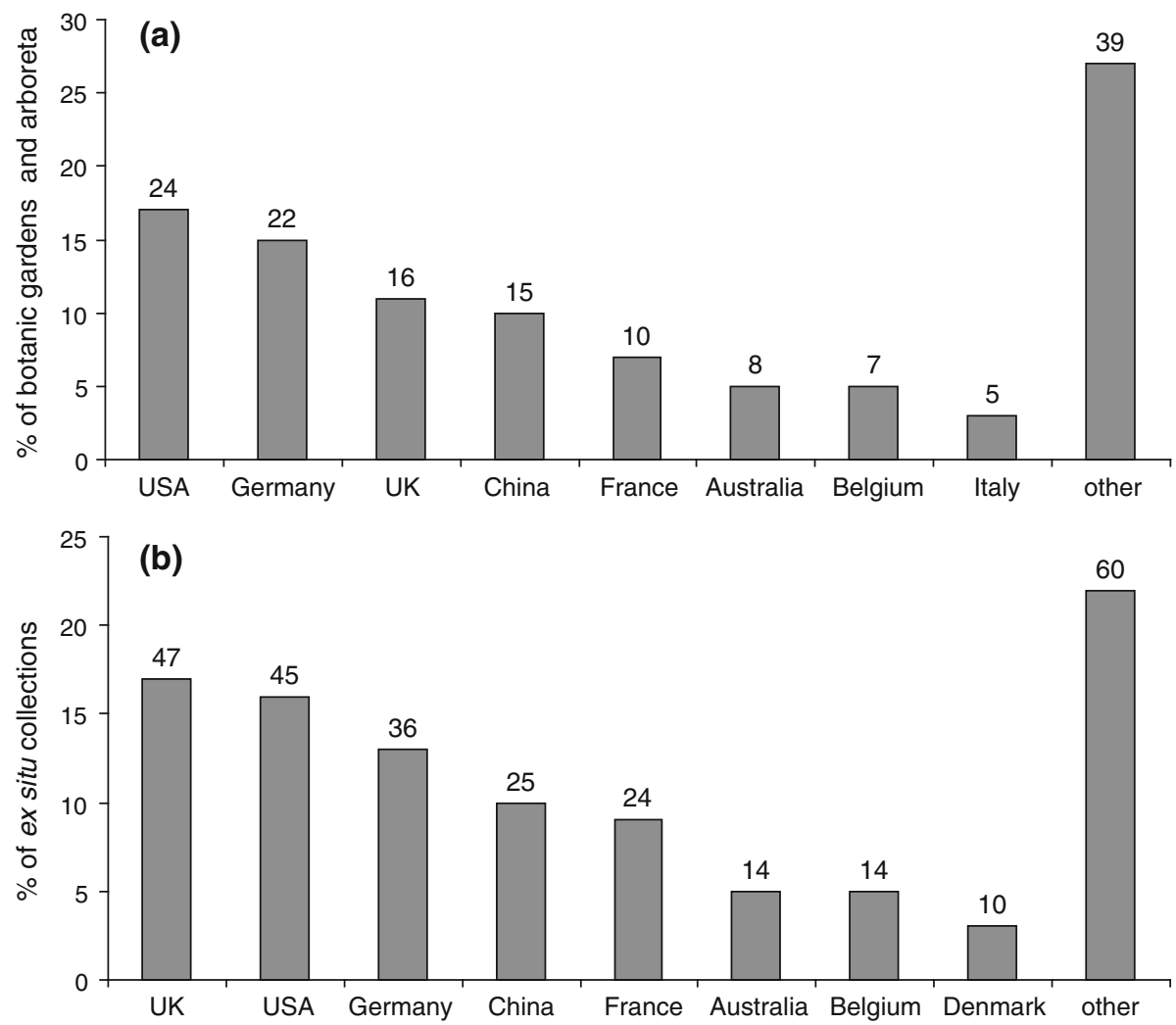

Fig. 1 Worldwide distribution of Zelkova ex situ collections surveyed. a Proportion of botanic gardens and arboreta per country possessing at least one ex situ collection. Numbers above the bars indicate the effective count of institutions. Only countries with 5 and more institutions are shown separately. b Proportion of ex situ collections per country. Only countries with 10 and more collections are shown separately. Numbers above the bars indicate the effective count of ex situ collections

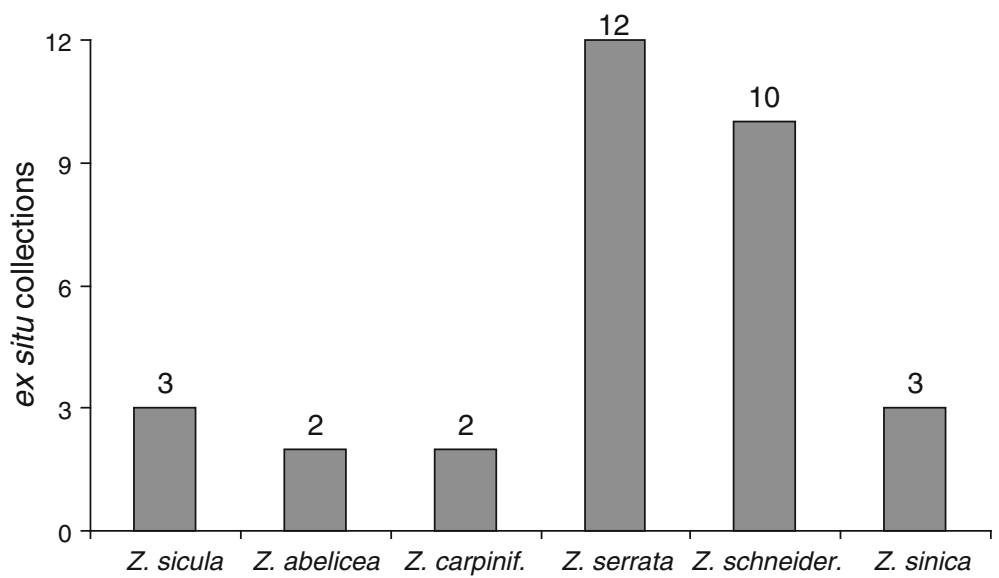

Fig. 2 Number of Zelkova ex situ collections held in the countries of their origin 


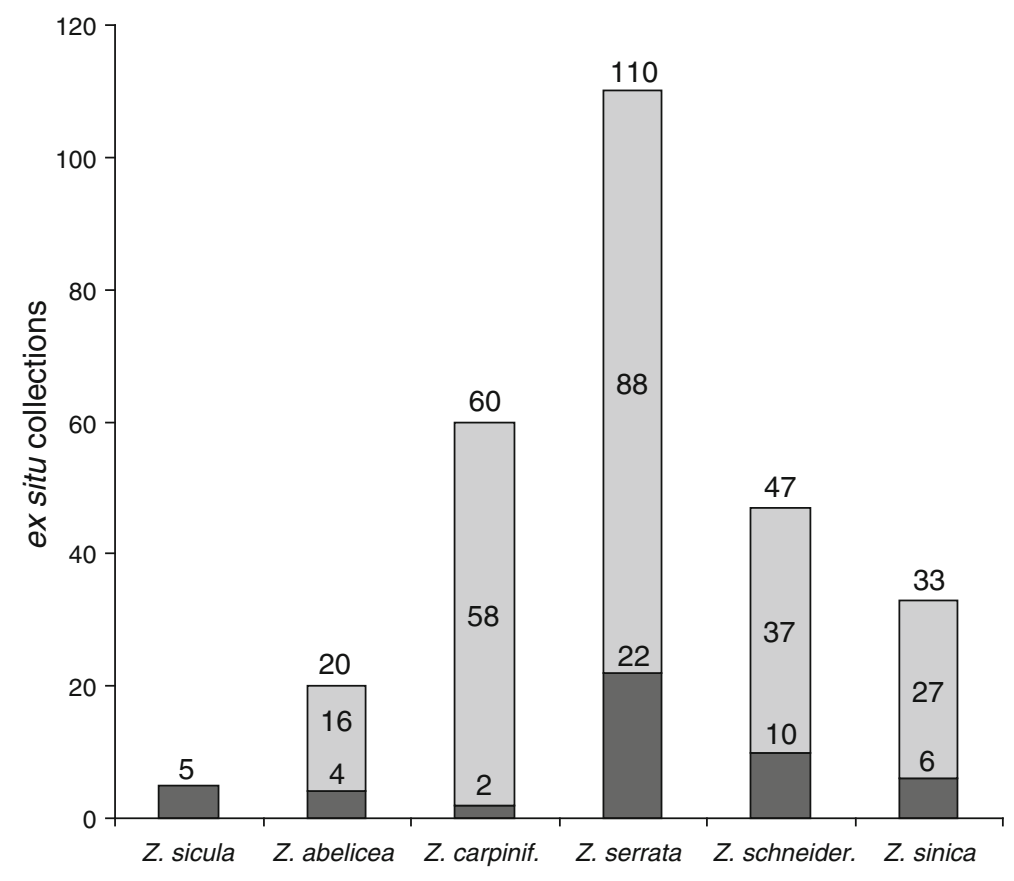

Fig. 3 Number of ex situ collections by source of material. Black (and lower numbers): collections of known wild provenance. Gray (and middle numbers): collections of horticultural or unknown source. Upper numbers: total count of ex situ collections of a given Zelkova species. For Z. sicula only one number is given since all ex situ collections stem from the first and only known population prior to 1991

\section{Discussion}

\section{Shortfalls of living ex situ collections}

Adopted at the Sixth Conference of the Parties to the Convention of Biological Diversity in 2002, the Global Strategy for Plant Conservation (GSPC), has reiterated the importance of ex situ conservation techniques, including living plant collections as well as seed, tissue, pollen and DNA storage (Wyse Jackson and Kennedy 2009). Specifically, Target 8 of the GSPC, calls for $75 \%$ of threatened plant species to be conserved in accessible ex situ collections, preferably in the country of origin (CBD 2011). At the same time The International Agenda for Botanic Gardens in Conservation (Wyse Jackson and Sutherland 2000) notes: "As a method of conservation, ex situ is inherently deficient in that is not usually possible to maintain more than a limited sample of the genetic diversity in cultivation or storage".

The global survey presented in this study is one of the first of its kind to shed light on the viability and limits of conservation of relict trees through living ex situ collections. The conclusions made in this study are also of wider relevance for other threatened plant species.

The total number of 275 Zelkova ex situ collection records identified in 146 botanic gardens and arboreta appears at first sight to be relatively high. However, Metasequoia glyptostroboides, to give an example of a relict tree discovered only 70 year ago (Hu and Cheng 1948), has ex situ collections in at least 187 institutions and many other ornamental 


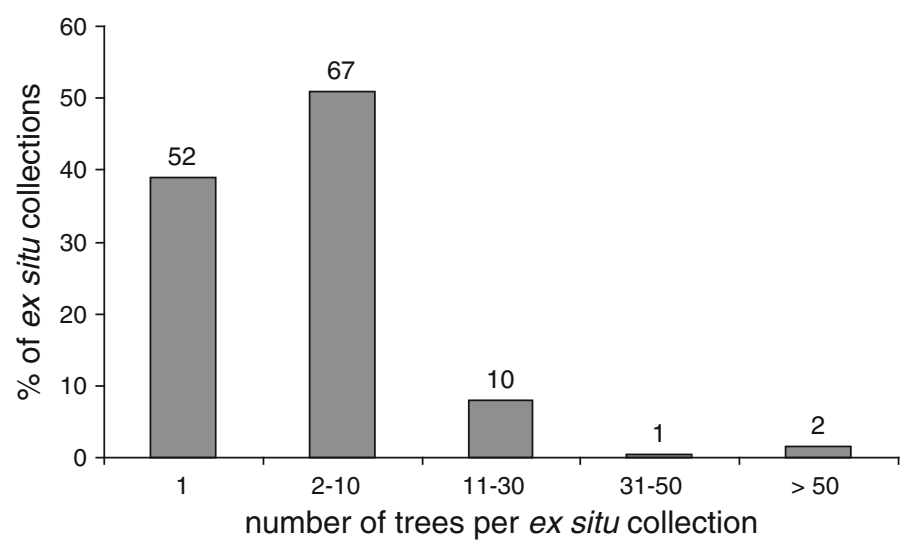

Fig. 4 Proportion of ex situ collections by their size, with all Zelkova species analyzed together. Numbers above the bars indicate the effective count of ex situ collections

tree genera are included in thousands of collections in numerous botanic gardens worldwide (Oldfield 2009).

One of the most striking results of our study, however, is the geographical distribution of the Zelkova ex situ collections. Although all known Zelkova taxa are held currently in botanic gardens and arboreta, relatively few collections exist in the countries of the species' natural distribution (Figs. 1, 2). The majority of botanic institutions with Zelkova collections are in countries with a strong horticultural tradition (e.g. USA, Germany, UK, France) and not in locations of their origin. This disproportion reflects the early, nonconservation orientated origin of tree collections planted almost exclusively for amenity reasons. It illustrates also the high proportion (in number and quality) of botanic gardens and arboreta in developed countries, mainly from Europe and North America (Golding et al. 2010) containing such collections.

More importantly, the acutely threatened Zelkova species are not the most represented in collections, and thus safeguarded through ex situ conservation. Of the 275 records included in the analysis, just 25 records of the most threatened Zelkova taxa, the Mediterranean Z. sicula and Z. abelicea were identified. This exemplifies also a particular challenge of botanic garden collections and their geographic representativeness in the Mediterranean. Maunder et al. (2004) have shown that Greece and Turkey (representing one of the most diverse plant areas of global importance) together have not more than 10 botanic gardens as compared to 80 in the United Kingdom. A similar situation applies to Chinese Zelkova taxa held in collections in China: Z. sinica with the smallest distributional range is represented lowest in numbers in Chinese ex situ collections. At the same time, Z. serrata with the widest natural distribution, is also the most common of the Zelkova species in botanic garden collections in China.

Limited information on the provenance of the cultivated material (Fig. 3) poses further challenges for science and conservation. Our Zelkova survey has demonstrated that more than $80 \%$ of all ex situ collections are not well documented. Not only is the origin of the plant material unknown but often also their taxonomic status and/or the cultivation history in the given institution. These collections are inappropriate for scientific study (e.g. phylogeny, phylogeography), and unsuitable for practical conservation, especially species and population recovery programmes. 
An additional problem is the size of the ex situ tree collections kept in botanic gardens and arboreta (Fig. 4) and with this the genetic representativeness of these collections. Although the need to address this challenge has been recognized for many years now (e.g. Ledig 1988; Cohen et al. 1991; Yang and Yeh 1992; Etisham-Ul-Haq et al. 2001), no significant improvements have been made in the last decades (Ensslin et al. 2011; Rucinska and Puchalski 2011). Namoff et al. (2010) proposed to collect at least 15 plants preferably from 3 accessions for purposes of maintaining genetic diversity. Other researchers proposed, however, that in order to establish a genetically representative ex situ collection some 50 populations per species and a minimum of 50 individuals per population should be represented per collection (Brown and Marshall 1995). None of the ex situ Zelkova collections surveyed in our study fulfils these recommendations, and figures remain below these benchmarks.

\section{Recommendations for Zelkova species}

Zelkova sicula from Sicily has been identified as the most threatened species in the genus (Garfî 2006). The situation of this narrow endemic taxon, discovered only in 1991 (Di Pasquale et al. 1992) is exceptional. Until recently, only one population was known worldwide. All ex situ collections in Sicily (3) and abroad (2 in France) originated from this unique population (Figs. 2, 3; Appendix S2). All plants of this population show very low genetic diversity, they are triploid and produce sterile seeds. Only vegetative propagation was possible to this date. This situation could change after the recent discovery of a new population in 2009, which shows more vigorous development and higher genetic diversity (Garfî et al. 2011). The species is now included in a comprehensive conservation plan initiated and supervised by its discoverer (G. Garfi, Istituto di Genetica Vegetale, CNR Palermo, Sicily). Both populations are fenced and will be soon legally protected. Wide-ranging scientific studies on $Z$. sicula have been carried out or are under way (e.g. concerning its biology, biogeography, phytosociology, population genetics, conservation status) (e.g. Nakagawa et al. 1998; Fineschi et al. 2002; Garfî et al. 2002). Nevertheless, Z. sicula remains a Critically Endangered species (IUCN Red List 2011: Garfî 2006). Securing the second newly discovered population is of immediate conservation interest, and is presently not represented in any ex situ collection (G. Garfi, personal communication). Creation of several new populations in climatically suitable and protected sites is desirable. Such assisted pioneer re-construction of Zelkova forests might provide a unique opportunity to explore and study ecosystem creation using ancient, nearly extinct relict trees.

The present conservation situation of the other Mediterranean species, Z. abelicea, is more secure since it is known from over 50 natural populations (Sondergaard and Egli 2006). Due to expanding road constructions, intensive grazing and other anthropogenic activities, however, the species remains very vulnerable and needs new conservation status assessments and detailed population surveys (Phitos et al. 1995). As with many other tree species in Crete, it has been logged since ancient times for its valuable timber, and its original distribution certainly diminished due to anthropogenic activity. To the present day, Z. abelicea provides stock fodder and its branches are often cut through pollarding for stake production and in handicrafts (Rackham and Moody 1996). Ex situ conservation of this species requires major planning and coordination efforts (Figs. 2, 3) including the establishment of well-documented collections in botanic gardens in Greece and especially in Crete. Collections should be created using plant material collected from all the mountain regions where Z. abelicea still occurs. Presently, the majority of the gardens cultivate 
Zelkova plants almost exclusively from the Levka Ori region, which has the most accessible large population and thus best known occurrence of $Z$. abelicea. In contrast, the populations from small, threatened and highly isolated populations of the Cretan Mountains (Psiloritis, Dhikti and Thripiti) have rarely if ever been used in ex situ cultivation. The practical conservation and propagation efforts carried out by Egli $(1993,1995,1997)$ and Sondergaard and Egli (2006) provide relevant guidance. Plants collected in the wild were cultivated in several botanic gardens, arboreta and private gardens in Crete, Switzerland, Norway and Denmark. Further surveys of these collections may yield valuable findings for future Z. abelicea conservation approaches. Conservation efforts and field studies conducted by the authors could be reactivated and included in local conservation action plans, ideally in collaboration with botanic gardens and/or other relevant scientific institutions in Crete.

Zelkova carpinifolia naturally grows in the south-caucasian countries of western Asia: Turkey, Georgia, Armenia, Azerbaijan and Iran (Güner and Zielinski 1998). It has been extensively logged for its valuable timber, famous for its visual attractiveness, lightness, flexibility and rot-resistance. The trees provide stock fodder and are often pollarded; branches are used for many purposes, for example as stakes in vineyards (Kvavadze and Connor 2005). In consequence, the species is rare and/or threatened in many regions. For example, in Turkey only very few and highly isolated populations are known (Davis 1982). In Trabzon, coastal region of Black Sea, a new subspecies Z. carpinifolia subsp. yamraensis was described by Anşin and Gercek (1991). However, there are no known ex situ conservation efforts for this taxon, although the last remaining population counts less than 10 individuals. Our survey has shown that Z. carpinifolia is very popular in botanic gardens worldwide (Fig. 3), ex situ cultivation in countries of its origin remains however, very limited (Fig. 2).

The Pan-Caucasian region where Z. carpinifolia naturally occurs is exceptionally rich in other relict trees (e.g. Albizia julibrissin, Diospyros lotus, Parrotia persica, Pterocarya fraxinifolia, Gleditsia caspica) (Mai 1995; Browicz and Zielinski 1982), and is considered as one of the most important refugial zones of Tertiary relict flora worldwide (Milne and Abbott 2002; Milne 2006). It would be highly desirable, therefore, to significantly improve regional and international conservation and ex situ cultivation efforts to secure relict trees in this region. Such efforts should be accompanied by new conservation status assessments and comprehensive field surveys.

Limited conservation status information is available on the three East-Asiatic Zelkova species, Z. schneideriana, Z. serrata and Z. sinica. Distributional data and many aspects of the biology and ecology of these species are poorly studied, and the description in the Flora of China (Zheng-yi and Raven 2003) concerns almost exclusively their morphology. The East-Asiatic Zelkova species are large trees (30-35 m tall) often used for the provision of high quality timber (e.g. Z. schneideriana) or in traditional herbal medicine (using bark and leaves of $Z$. serrata). None of these three taxa have been assessed against IUCN's Red List Categories and Criteria (IUCN 2001). In many regions they are overexploited (Zheng-yi and Raven 2003) and/or threatened by habitat fragmentation (Fang et al. 2007). Zelkova serrata is the most popular of the three East-Asiatic species cultivated in botanic gardens and arboreta (Fig. 3), but also in urban parks and private gardens. With 12 surveyed collections in the countries of its origin, and 22 collections of known provenance (Figs. 2, 3 ), it is also the best secured taxon of the genus. Z. schneideriana and Z. sinica are Chinese endemics growing mainly in the vicinity of streams and rivers with large altitudinal amplitude between 200 and 2,800 m a.s.l. (Zheng-yi and Raven 2003). Although their ex situ cultivation is more developed than that of the Mediterranean Zelkova species, it is 
essential to also establish well-documented representative collections in China (Figs 2, 3). This is especially the case for Z sinica, with only three Chinese and six global ex situ collections of known origin. Thus, similarly to Z. carpinifolia, significant improvement of regional and international coordination of ex situ cultivation and increase in the number of well-documented ex situ collections are needed. New conservation status assessments for East-Asiatic Zelkova taxa and comprehensive field surveys should be undertaken to more accurately determine the species' current threat situation.

General recommendations for conservation of relict trees via living ex situ collections

To secure the survival of threatened relict trees in the long run, international coordination between botanic gardens and arboreta needs to be significantly improved. Additionally, maintaining of living ex situ collections should ideally be part of an overall conservation strategy including other actors (local administration, national parks, foresters, etc.) as well as other ex situ and in situ approaches, which can be exemplified by successful conservation of Abies nebrodensis (Raimondo and Schicchi 2005; Saporito et al. 2009). Such integrated conservation actions, therefore, should be always chosen for relict trees with extremely low number of remaining individuals or for species not reproducing sexually, which is clearly the case for Z. sicula.

Thus, a number of scientific questions remain to be answered, particularly how to establish and maintain living ex situ collections that represent the entire range of the taxa's genetic diversity including the scientific documentation of the provenance data. The following general conclusions and recommendations are drawn from our survey concerning the conservation of the relict trees by means of living ex situ collections:

1. Establishment of a global priority list of the most important relict trees including their global conservation status.

2. Botanic gardens and arboreta in regions and countries with emblematic relict trees should integrate the ex situ conservation of these taxa into their conservation strategies and action plans.

3. For relict genera with several species, conservation priority should be given to the most threatened taxa and/or to narrow endemics.

4. Botanic gardens and arboreta should ensure that their ex situ collections and associated data (e.g. list of relict trees in cultivation, their origin and collection size) are accessible to the scientific and conservation community.

5. Botanic gardens and arboreta should develop public awareness and outreach programmes in regions where relict tree species are most at threat. As with all successful conservation activities, the involvement of local communities and organisations is critical to the long term conservation of threatened species, and should be encouraged and supported from the earliest stages of conservation planning.

6. For newly created ex situ collections only well-documented plant material with detailed information on its origin should be used, while for existing, often very old collections, a thorough investigation of the provenance data for all relict trees in cultivation should be undertaken.

7. Large scale genetic studies should be undertaken, ideally at genus level, in order to verify and/or clarify provenance of ex situ collections of threatened relict trees in cultivation. 
8. Further research concerning the minimum number of cultivated trees per botanic garden and taxon in order to assure the conservation of a maximum of the genetic diversity for a given taxon should be carried out.

9. For the most threatened relict tree species and/or genera, well-coordinated specialist groups should be created in order to act globally and to develop a long term ex situ conservation strategy for these taxa. These specialist groups should define, among others, the geographical distribution of ex situ collections and assure the genetic and biogeographical representativeness of used plant material.

10. Botanic Gardens Conservation International (http://www.bgci.org) and the Global Tree Specialist Group of the Species Survival Commissions of IUCN (http:// www.globaltrees.org) are ideally placed to coordinate the development of comprehensive global ex situ conservation research and action for threatened relict trees through its numerous botanic garden members and affiliated partners.

Acknowledgements We are indebted to Fondation Franklinia for its generous support to undertake this study. We would also like to thank B. Clement, H. Castella and S. Bollinger from the Botanical Garden of the University of Fribourg (Switzerland) for their assistance during the manuscript preparation. Many botanic gardens around the world have provided data to the survey (see Appendix S2); their contributions are gratefully acknowledged. We would also like to acknowledge the assistance of the following organizations in the dissemination of the survey and the collection of data: American Public Gardens Association, Botanic Gardens Committee of the Chinese Academy of Sciences (CAS) and European Botanic Gardens Consortium.

\section{References}

Ahanjan M, Mohana DC, Raveesha KA, Azadbakht M (2007) Antibacterial potential of extracts of leaves of Parrotia persica. Afr J Biotechnol 6:2526-2528

Anşin R, Gercek Z (1991) A new Zelkova taxon for the flora of Turkey: Zelkova carpinifolia (Pall.) C. Koch subsp. yamraensis Anşin \& Gercek, subsp. nova. Doga. Turk J Agric For 15:564-575

BGCI (2010) Botanic gardens conservation international. Global survey of ex situ Zelkova collections. http://www.bgci.org/files/survey-zelkova.pdf. Accessed April 2011

Bibalani GH, Majnonian B, Adeli E, Sanii H (2006) Slope stabilization with Gleditsia caspica and Parrotia persica. Int J Environ Sci Technol 2:381-385

Browicz K, Zielinski J (1982) Chorology of trees and shrubs in south-west Asia and adjacent regions. Polish Academy of Sciences, Institute of Dendrology, Bogucki Wydawnictwo Naukowe, Poznan

Brown AHD, Marshall DR (1995) A basic sampling strategy: theory and practice. In: Gaurino L, Ramanatha Rao V, Reid R (eds) Collecting plant genetic diversity: technical guidelines. CAB International, Wallingford, pp 75-91

Burney DA, Burney LP (2007) Paleoecology and “inter-situ” restoration on Kaui'a, Hawai'i. Front Ecol Environ 5:483-490

Burnham RJ (1986) Foliar morphological analysis of the Ulmoideae (Ulmaceae) from the early tertiary of western North America. Palaeontogr Abt B 201:135-167

CBD (2011) Convention on biological diversity. http://www.cbd.int/decision/cop/?id=12283. Accessed April 2011

Chaw S-M, Parkinson CL, Cheng Y, Vincent TM, Palmer DJ (2000) Seed plant phylogeny inferred from all three plant genomes: monophyly of extant gymnosperms, and origin of Gnetales from conifers. Proc Natl Acad Sci 97:4086-4091

Cochrane JA, Barrett S, Monks L, Dillon R (2010) Partnering conservation actions. Inter situ solutions to recover threatened species in South West Western Australia. Kew Bull 65:655-662

Cohen JI, Williams JT, Plucknett DL, Shands H (1991) Ex situ conservation of plant genetic resources: global development and environmental concerns. Science 253:866-872 
Costanza R, d'Arge R, de Groot R, Farber S, Grasso M, Hannon B, Limburg K, Naeem S, O’Neill RV, Paruelo J, Raskin RG, Sutton P, van den Belt M (1997) The value of the world's ecosystem services and natural capital. Nature 387:253-260

Davis P (1982) Flora of Turkey and the East Aegean Islands. Edinburgh

Del Tredici J, Ling H, Yang G (1992) The Ginkgos of Tian Mu Shan. Conserv Biol 6:202-209

Denk T, Grimm GW (2005) Phylogeny and biogeography of Zelkova (Ulmaceae sensu stricto) as inferred from leaf morphology, ITS sequence data and the fossil record. Bot J Linn Soc 147:129-157

Di Pasquale G, Garfi G, Quezél P (1992) Sur la présence d'un Zelkova nouveau en Sicile sudorientale (Ulmaceae). Biocosme Mésogéen 8-9:401-409

Donaldson JS (2009) Botanic gardens science for conservation and global change. Trends Plant Sci $14: 608-613$

Egli B (1993) Ökologie der Dolinen im Gebirge Kretas (Griechenland). PhD thesis, ETH Zürich

Egli B (1995) Zelkova abelicea (Lam.) Boiss. In: Phitos D, Strid A, Snogerup S, Greuter W (eds) The red data book of rare and threatened plants of Greece. K. Michalas WWF, Athens, pp 526-527

Egli B (1997) A project for the preservation of Zelkova abelicea (Ulmaceae), a threatened endemic tree species from the mountains of Crete. Bocconea 5:505-510

Ensslin A, Sandner TM, Matthies D (2011) Consequances of ex situ cultivation of plants: genetic diversity, fitness and adaptation of the monocarpic Cynoglossum officinale L. in botanic gardens. Biol Conserv 144:272-278

Etisham-Ul-Haq M, Allnutt TR, Smith-Ramirez C, Gardner MF, Armesto JJ, Newton AC (2001) Patterns of genetic variation in in and ex situ populations pf the threatened Chilean vine Berberidopsis carollina, detected using RAPD markers. Ann Bot 87:813-821

Fang Y, Liu S, Xiang J, Ge J (2007) Study on the natural population distribution of Zelkova schneideriana in Hubei. Res Environ Yangtze Basin 16:744

Fernandez X, Lizzani-Cuvelier L, Loiseau A-M, Perichet C, Delbecque C, Arnaudo J-F (2005) Chemical composition of the essential oils from Turkish and Honduras Styrax. Flavour Fragr J 20:70-73

Fineschi S, Anzidei M, Cafasso D, Cozzolino S, Garfi G, Pastorelli R, Salvini D, Turchini D, Vendramin GG (2002) Molecular markers reveal a strong genetic differentiation between two European relic tree species: Zelkova abelicea (Lam.) Boissier and Z. sicula Di Pasquale, Garfi \& Quézel (Ulmaceae). Conserv Gen 3:145-153

Garfî G (2006) Zelkova sicula. IUCN 2010. IUCN red list of threatened species. Version 2010.4. http://www.iucnredlist.org. Accessed Feb 2011

Garfî G, Barbero M, Tessier L (2002) Architecture and growth patterns of Zelkova sicula (Ulmaceae) in south-east Sicily as a response to environmental conditions. J Medit Ecol 3:65-76

Garfî G, Carimi F, Pasta S, Rühl J, Trigila S (2011) Additional insights on the ecology of the relic tree Zelkova sicula di Pasquale, Garfi et Quétzal (Ulmaceae) after the finding of new population. Flora 206:407-417

Golding J, Güsewell S, Kreft H, Kuzevanov VY, Lehvävirta S, Parmantier I, Pautasso M (2010) Speciesrichness patterns of the living collections of the world's botanic gardens: a matter of socio-economics? Ann Bot 105:689-696

Guerrant EO Jr, Havens K, Maunder M (eds) (2004) Ex situ plant conservation. Supporting species survival in the wild. Island Press, Washington

Güner A, Zielinski J (1998) Zelkova carpinifolia. IUCN 2010. IUCN red list of threatened species. Version 2010.4. http://www.iucnredlist.org. Accessed Feb 2011

$\mathrm{Hu} \mathrm{HH}$, Cheng WC (1948) On the new families Metasequoiaceae and on Metasequoia glyptostroboides, a living species of the genus Metasequoia found in Szechuang and Hupeh. Bull Fan Mem Inst Biol $1: 153-163$

IUCN (2001) International Union for Conservation of Nature. Red List Categories and Criteria: Version 3.1. Gland, Switzerland. http://www.iucnredlist.org. Accessed Feb 2011

Iverson LR, Prasad AM (2001) Potential changes in tree species richness and forest community types following climate change. Ecosystems 4:186-199

Kvavadze EV, Connor SE (2005) Zelkova carpinifolia (Pallas) K. Koch in Holocene sediments of Georgiaan indicator of climatic optima. Rev Palaeobot Palynol 133:69-89

Ledig FT (1988) The conservation of diversity in forest trees. Why and how should genes be conserved? Bioscience 38:471-479

Li F, Xi N (2005) Population structure and genetic diversity of an endangered species, Glyptostrobus pensilis (Cupressaceae). Bot Bull Acad Sin 46:155-162

Loreau M, Naeem S, Inchausti P, Bengtsson J, Grime JP, Hector A, Hooper DU, Huston MA, Raffaelli D, Schmid B, Tilman D, Wardle DA (2001) Biodiversity and ecosystem functioning: current knowledge and future challenges. Science 294:804-808 
Mahvi AH, Nouri J, Omrani GA, Gholami F (2007) Application of Platanus orientalis leaves in removal of cadmium from aqueous solution. World App Sci J 2:40-44

Mai DH (1995) Tertiäre Vegetationsgeschichte Europas. Methoden und Ergebnisse. Gustav Fischer, Jena

Maunder M, Havens K, Guerrant EO Jr, Falk DA (2004) Ex situ methods: a vital but underused set of conservation resources. In: Guerrant EO Jr, Havens K, Maunder M (eds) Ex situ plant consetvation. Supporting species survival in the wild. Island Press, Washington, pp 3-20

Melillo JM (1999) Climate change-warm, warm on the range. Science 283:183-184

Milne RI (2006) Northern Hemisphere plant disjunctions: a window on tertiary land bridges and climate change? Ann Bot 98:465-472

Milne RI, Abbott RJ (2002) The origin and evolution of tertiary relict floras. Adv Bot Res 38:281-314

Nakagawa T, Garfi G, Reille M, Verlaque R (1998) Pollen morphology of Zelkova sicula (Ulmaceae), a recently discovered relic species of the European Tertiary flora: description, chromosomal relevance, and palaeobotanical significance. Rev Palaeobot Palynol 100:27-37

Namoff S, Husby CE, Francisco-Ortega J, Noblick LR, Lewis CE, Griffith MP (2010) How well does a botanic garden collection of rare palm capture the genetic variation in a wild population? Biol Conserv 143:1110-1117

Oldfield SF (2009) Botanic gardens and the conservation of tree species. Trends Plant Sci 14:581-583

Owens SJ, Rix M (2007) Franklinia alatamaha, Theaceae. Curtis's Bot Mag 24:186-189

Petit RJ, Hampe A, Cheddadi R (2005) Climate change and tree phylogeography in the Mediterranean. Taxonomy 54:877-885

Phitos D, Strid A, Snogerup S, Greuter W (eds) (1995) The red data book of rare and threatened plants of Greece. K. Michalas WWF, Athens

Powledge F (2011) The evolving role of botanical gardens. Bioscience 61:743-749

Quézel P, Médail F (2003) Ecologie et biogeography des forêts du bassin méditerranéen. Elsevier, Paris

Rackham O, Moody J (1996) The making of the Cretan landscape. Manchester University Press, Manchester and New York

Raimondo FM, Schicchi R (eds) (2005) Conservazione in situ ed ex situ di Abies nebrodensis (Lojac.) Mattei: progetto LIFE Natura no LIFE2000NAT/IT/7228 - Petralia Sottana: Parco delle Madonie

Rucinska A, Puchalski J (2011) Comparative molecular studies on the genetic diversity of an ex situ garden collection and its source population of the critically endangered polish endemic plant Cochlearia polonica E. Fröhlich. Biodiv Conserv 20:401-413

Sadighara P, Ashrafihelan J, Barin A, Ali Esfahani T (2009) Histopathology and cholinergic assessment of Pterocarya fraxinifolia on chicken embryo. Interdiscip Toxicol 2:254-256

Saporito L, De Carlo A, Emiliani G, Paffetti D, Vettori C, Giannini R (2009) Biodiversità e conservazione di specie forestali endemiche e relitte in Sicilia. Atti del Terzo Congresso Nazionale di Selvicoltura. Taormina, 16th-19th Oct 2008. Accademia Italiana di Scienze Forestali, Firenze, pp 265-270

Sefidi K, Marvie Mohadjer MR, Etemad V, Copenheaver CA (2011) Stand characteristics and distribution of relict population of Persian ironwood (Parrotia persica C.A. Meyer) in northern Iran. Flora 206:418-422

Sondergaard P, Egli BR (2006) Zelkova abelicea (Ulmaceae) in Crete: floristics, ecology, propagation and threats. Willdenowia 36:317-322

Tang CQ, Yang Y, Ohsawa M, Momohara A, Hara M, Cheng S, Fan S (2011) Population structure of relict Metasequoia glyptostroboides and its habitat fragmentation and degradation in south-central China. Biol Conserv 144:279-289

Uma Shaanker R, Ganeshaiah KN, Nageswara Rao M, Aravind NA (2002) Ecological consequences of forest use: from genes to ecosystems. A case study in the Iiligiri Rangaswamy Temple Wildlife Sanctuary, South India. Conserv Soc 22:347-363

Volis S, Blecher M (2010) Quasi in situ: a bridge between ex situ and in situ conservation of plants. Biol Conserv. doi:10.1007/s10531-010-9849-2

Wiegrefe SJ, Sytsma KJ, Guries RP (1998) The Ulmaceae, one family or two? Evidence from chloroplast DNA restriction site mapping. Plant Syst Evol 210:249-270

Wyse Jackson P, Kennedy K (2009) The global strategy for plant conservation: a challenge and opportunity for the international community. Trends Plant Sci 14:578-580

Wyse Jackson P, Sutherland LA (2000) International agenda for botanic gardens in conservation. Botanic Gardens Conservation International, Richmond, pp 1-56

Yang R-C, Yeh FC (1992) Genetic consequences if in situ and ex situ conservation of forest trees. Fores Chron 68:720-729

Zhao Y, Paule J, Fu C, Koch MA (2010) Out of China: distribution history of Ginkgo biloba L. Taxonomy 59:495-504 
Zheng L, Zheng J, Zhao Y, Wang B, Wu L, Liang H (2006) Three anti-tumor saponins from Albizia julibrissin. Bioorg Med Chem Lett 16:2765-2768

Zheng-yi W, Raven PH (2003) Zelkova. Flora of China. vol 5. Ulmaceae-Basellaceae. Missouri Botanical Garden Press, St. Louis, pp 10-11 